\title{
PENGARUH PENERAPAN MODEL INDUCTIVE THINKING BERBASIS KETERAMPILAN PROSES SAINS UNTUK MENINGKATKAN KEMAMPUAN KOGNITIF DAN KETERAMPILAN BERFIKIR KREATIF MAHASISWA PGSD
}

\author{
Fahrur Rozi, Septian Prawija, Imelda Free Unita Manurung \\ Surel: rozipgsd2015@gmail.com
}

\begin{abstract}
ABSTRAK
Penelitian ini bertujuan untuk meningkatkan kualitas pembelajaran IPA pada sekolah dasar melalui mata kuliah konsep dasar IPA. Hasil dari penelitian ini kiranya dapat memberikan gambaran mengenai pengaruh perbedaan peningkatan kemampuan kognitif dan keterampilan berfikir kreatif mahasiswa PGSD pada mata kuliah konsep dasar IPA menggunakan model pembelajaran inductive thinking berbasis keterampilan proses sains dengan tanpa berbasis keterampilan proses sains. Penelitian dilakukan menggunakan metode eksperimen semu. Dalam penelitian ini, subyek penelitian dibagi ke dalam dua kelas, satu kelas digunakan sebagai kelas eksperimen dan satu kelas lagi sebagai kelas kontrol, dimana penentuan kelas kontrol dan kelas eksperimen dilakukan secara acak.
\end{abstract}

Kata Kunci: Inductive Thinking, Keterampilan Proses Sains, Berfikir Kreatif

\section{PENDAHULUAN}

Dalam upaya untuk mewujudkan pendidikan yang berkualitas tersebut maka pemerintah terus berusaha untuk mengembangkan sistem pendidikan. Salah satu ilmu pengetahuan yang mampu meningkatkan kualitas pendidikan adalah ilmu pengetahuan alam (IPA) dan salah satu pihak yang banyak menjadi pusat perhatian dalam peningkatan mutu pendidikan adalah guru, bahkan dinyatakan bahwa guru memberikan kontribusi terbesar (sebesar 34\%) terhadap prestasi belajar siswa di sekolah (Heyneman \& Locky, dalam Fattah, 2000). Cara guru mengajarkan konsep IPA yang sulit dipahami siswa turut berkontribusi terhadap rendahnya pemahaman konsep IPA siswa. Membicarakan guru berarti melibatkan lembaga pencetak tenaga pendidik (LPTK). Untuk itu perlu dipersiapkan tenaga guru SD dalam Pendidikan Guru Sekolah Dasar (PGSD) yang baik agar konsep IPA yang diajarkan di sekolah dasar dapat dipahami oleh siswa.

Mahasiswa PGSD berasal dari beberapa latar belakang pendidikan. Sekitar $40 \%$ mahasiswa berlatar belakang pendidikan IPA dan $60 \%$ berlatar belakang IPS. Disamping itu

Dosen PGSD Universitas Negeri Medan 
terdapat peningkatan jumlah mahasiswa yang berlatar belakang SMK. Hal ini menuntut cara membelajarkan Konsep Dasar IPA yang dapat dipahami oleh beragam latar belakang pendidikan tersebut.

Kenyataan ini mengisyaratkan perlunya suatu solusi. Salah satunya adalah dengan menerapkan model pembelajaran inductive thinking berbasis keterampilan proses sains. Penelitian ini bertujuan untuk untuk meningkatkan kemampuan kognitif dan keterampilan berfikir kreatif mahasiswa PGSD pada mata kuliah konsep dasar IPA.

Adapun rumusan masalah dalam penelitian ini ialah:

1. Bagaimana peningkatan kemampuan kognitif dan mahasiswa yang mendapatkan pembelajaran dengan model pembelajaran inductive thinking berbasis keterampilan proses sains dibandingkan mahasiswa yang mendapatkan model pembelajaran inductive thinking?

2. Bagaimana peningkatan kreatif mahasiswa yang mendapatkan pembelajaran dengan model pembelajaran inductive thinking berbasis keterampilan proses sains dibandingkan mahasiswa yang mendapatkan model pembelajaran inductive thinking?

Berdasarkan rumusan masalah di atas, tujuan dari penelitian ini adalah untuk:
1. Mendapatkan gambaran tentang perbedaan peningkatan kemampuan kognitif antara mahasiswa yang mendapatkan pembelajaran dengan model pembelajaran inductive thinking berbasis keterampilan proses sains dibandingkan mahasiswa yang mendapatkan model pembelajaran inductive thinking.

2. Mendapatkan gambaran tentang perbedaan peningkatan keterampilan berfikir kreatif antara mahasiswa yang mendapatkan pembelajaran dengan model pembelajaran inductive thinking berbasis keterampilan proses sains dibandingkan mahasiswa yang mendapatkan model pembelajaran inductive thinking.

Penelitian ini diharapkan dapat memberikan manfaat bagi pihak mahasiswa, Guru/Dosen, dan LPTK. Mahasiswa PGSD yang terlibat selama penelitian ini diharapkan memperoleh pengetahuan dan keterampilan yang lebih baik mengenai pembelajaran IPA untuk siswa di SD. Model pembelajaran atau perkuliahan yang mengintegrasikan mata kuliah konsep dasar IPA dan pendidikan IPA bagi mahasiswa PGSD yang dirancang dan dikembangkan dalam penelitian ini diharapkan dapat digunakan sebagai salah satu alternatif bagi pembelajaran IPA SD. Bagi LPTK, upaya mengintegrasikan mata kuliah 
konsep dasar IPA dan pendidikan IPA yang telah dilakukan dalam penelitian ini dapat dianggap sebagai masukan untuk pengembangan mata kuliah IPA bagi mahasiswa PGSD pada waktu yang akan datang.

\section{METODE PENELITIAN}

Metode yang digunakan dalam penelitian ini adalah metode eksperimen semu (quasi eksperiment), yaitu penelitian yang secara khas meneliti mengenai keadaan praktis yang didalamnya tidak mungkin untuk mengontrol semua variabel yang relevan (Sugiyono, 2006:14).

Desain penelitian yang digunakan dalam penelitian ini adalah desain randomized control group pretest-postest design.

Tabel 3.1. Desain Penelitian

\begin{tabular}{|c|c|c|c|}
\hline Kelas & Pretest & Perlakuan & Posttest \\
\hline Eksperimen & $\mathrm{O}_{1} \mathrm{O}_{2}$ & $\mathrm{X}_{1}$ & $\mathrm{O}_{1} \mathrm{O}_{2}$ \\
\hline Kontrol & $\mathrm{O}_{1} \mathrm{O}_{2}$ & $\mathrm{X}_{2}$ & $\mathrm{O}_{1} \mathrm{O}_{2}$ \\
\hline
\end{tabular}

Keterangan :

$\mathrm{O}_{1}$ : Pretest-posttest untuk mengukur kemampuan kognitif mahasiswa.

$\mathrm{O}_{2}$ : Pretest-posttest untuk mengukur keterampilan berfikir kreatif mahasiswa.

$\mathrm{X}_{1}$ : Perlakuan berupa model pembelajaran inductive thinking berbasis keterampilan proses sains.

$\mathrm{X}_{2}$ : Perlakuan berupa model pembelajaran inductive thinking.

Populasi dalam penelitian ini adalah seluruh kelas mahasiswa
PGSD yang mengambil mata kuliah Konsep Dasar IPA. Sampel penelitian ini adalah dua kelas mahasiswa PGSD. Teknik pengambilan sampel adalah dengan cara cluster random sampling yaitu sebagai sampel penelitian dipilih dua kelas secara acak yang memiliki kemampuan yang hampir setara tanpa mengacak mahasiswa tiap kelasnya.

Variabel penelitian dalam penelitian ini terdiri dari variabel bebas dan variabel terikat. Adapun variabel terikat pada penelitian ini adalah kemampuan kognitif dan keterampilan berfikir kreatif, sedangkan untuk variabel bebas pada penelitian ini adalah model pembelajaran inductive thinking berbasis keterampilan proses sains

Langkah-langkah yang akan dilakukan dalam penelitian ini dibagi menjadi tiga tahapan, yaitu:

a. Tahap Persiapan

Kegiatan yang dilakukan pada tahap persiapan meliputi:

1. Menentukan masalah yang akan dikaji. Untuk menentukan masalah yang akan dikaji, peneliti melakukan studi pendahuluan melalui kegiatan observasi, yaitu mengamati kegiatan pembelajaran fisika di dalam kelas, penyebaran skala sikap kepada mahasiswa serta melakukan wawancara terhadap guru mata pelajaran fisika dan beberapa mahasiswa.

2. Studi literatur, dilakukan untuk memperoleh teori yang akurat 
mengenai permasalahan yang akan dikaji.

3. Melakukan studi kurikulum mengenai materi ajar yang dijadikan penelitian untuk mengetahui kompetensi dasar yang hendak dicapai.

4. Menyusun rencana pelaksanaan pembelajaran dan skenario pembelajaran yang mengacu pada tahapan model pembelajaran inductive thinking berbasis keterampilan proses sains.

5. Membuat dan menyusun instrumen penelitian.

6. Melakukan uji coba instrumen penelitian.

7. Menganalisis hasil uji coba instrumen penelitian dan kemudian menentukan soal yang layak digunakan sebagai instrumen penelitian.

b. Tahap Pelaksanaan

Kegiatan yang dilakukan pada tahap pelaksanaan meliputi:

1. Memberikan tes awal (pretest).

2. Memberikan perlakuan pada kedua kelas yang berbeda yaitu dengan cara menerapkan model pembelajaran inductive thinking berbasis keterampilan proses sains dan model pembelajaran inductive thinking.

3. Memberikan tes akhir (posttest).

c. Tahap Akhir

Pada tahapan ini kegiatan yang akan dilakukan antara lain:

1. Mengolah data hasil pretest dan posttest serta menganalisis instrumen tes lainnya.

2. Memberikan kesimpulan berdasarkan hasil yang diperoleh dari pengolahan data.

3. Memberikan saran-saran terhadap aspek-aspek penelitian yang kurang sesuai.

Teknik pengumpulan data dalam penelitian ini adalah menggunakan lembar keterlaksanaan model pembelajaran, tes pemahaman konsep, tes untuk mengetahui miskonsepsi mahasiswa dan skala sikap mahasiswa terhadap pelaksanaan pembelajaran.

Tabel 3.2. Teknik Pengumpulan

\begin{tabular}{|c|l|l|l|}
\hline \multicolumn{2}{|c}{ Data } \\
\hline No & Jenis Data & $\begin{array}{c}\text { Teknik } \\
\text { Pengumpulan } \\
\text { Data }\end{array}$ & Keterangan \\
\hline 1 & $\begin{array}{l}\text { Kemampuan } \\
\text { Kognitif }\end{array}$ & $\begin{array}{l}\text { Tes pilihan } \\
\text { berganda }\end{array}$ & $\begin{array}{l}\text { Pelaksanaan di } \\
\text { awal dan di } \\
\text { akhir } \\
\text { pembelajaran }\end{array}$ \\
\hline 2 & $\begin{array}{l}\text { Keterampilan } \\
\text { berfikir kreatif }\end{array}$ & $\begin{array}{l}\text { Tes pilihan } \\
\text { berganda }\end{array}$ & $\begin{array}{l}\text { Pelaksanaan di } \\
\text { awal dan di } \\
\text { akhir } \\
\text { pembelajaran }\end{array}$ \\
\hline 3 & $\begin{array}{l}\text { Sikap } \\
\text { mahasiswa } \\
\text { terhadap } \\
\text { pembelajaran }\end{array}$ & $\begin{array}{l}\text { Skala sikap } \\
\text { Pelaksanaan di } \\
\text { akhir } \\
\text { pembelajaran } \\
\text { (skala sikap) }\end{array}$ \\
\hline 4 & $\begin{array}{l}\text { Keterlaksanaan } \\
\text { model } \\
\text { pembelajaran } \\
\text { oleh guru dan } \\
\text { mahasiswa }\end{array}$ & $\begin{array}{l}\text { Lembar } \\
\text { Observasi }\end{array}$ & $\begin{array}{l}\text { Pelaksanaan } \\
\text { selama proses } \\
\text { pembelajaran } \\
\text { (lembar } \\
\text { observasi) }\end{array}$ \\
\hline
\end{tabular}

Instrumen yang digunakan dalam penelitian ini terdiri dari:

a. Tes Kemampuan Kognitif

Berbentuk pilihan berganda yang dikembangkan dari beberapa 
aspek dan indikator. Jumlah pilihan yang diberikan sebanyak lima pilihan. Sebelum digunakan instrumen ini dikonsultasikan dengan dosen pembimbing, judgement oleh para ahli, diujicobakan dan dilakukan analisis untuk mengetahui realibilitas, tingkat kesukaran dan daya beda.

\section{b. Tes keterampilan berpikir kreatif Tes ini mencakup} keterampilan bertanya, katerampilan menerka sebab-sebab suatu kejadian, katerampilan menerka akibat-akibat suatu kejadian, dan keterampilan memperbaiki hasil. Tes keterampilan berpikir kreatif dikonstruksi dalam bentuk tes pilihan berganda. Tes keterampilan berpikir kreatif diberikan sebanyak dua kali, yaitu di awal (tes awal) dan akhir (tes akhir) sebelum perlakuan maupun setelah perlakuan. Tes ini bertujuan untuk mengukur keterampilan berpikir kreatif sebelum dan sesudah perlakuan diberikan. Tes awal digunakan untuk melihat kondisi awal subyek penelitian berkaitan keterampilan berpikir kreatif. Hasil tes ini akan dihitung gain yang dinormalisasi $\langle\mathrm{g}\rangle$ digunakan untuk melihat peningkatan keterampilan berpikir kreatif.

\section{c. Skala Sikap Mahasiswa terhadap Pembelajaran}

Skala sikap ini digunakan untuk memperoleh informasi tentang tanggapan mahasiswa terhadap penerapan model pembelajaran. Skala sikap ini memuat daftar pertanyaan terkait penerapan model pembelajaran yang akan dilaksanakan. Instrumen skala sikap tanggapan ini memuat kolom sangat setuju (SS), setuju (S), tidak setuju (TS), dan dan sangat tidak setuju (STS). Mahasiswa diminta memberikan tanda cek $(\sqrt{ })$ pada pernyataan yang terdapat pada skala sikap.

d. Lembar Keterlaksanaan Model Pembelajaran oleh Dosen dan Mahasiswa

Lembar keterlaksanaan model pembelajaran oleh dosen dan mahasiswa ini memuat daftar keterlaksanaan model pembelajaran yang akan dilaksanakan. Instrumen keterlaksanaan model pembelajaran ini berbentuk rating scale yang memuat kolom ya dan tidak, dimana observer hanya memberikan tanda cek $(\sqrt{ })$ pada kolom yang sesuai dengan aktivitas yang diobservasi mengenai keterlaksanaan model pembelajaran yang akan diterapkan.

Instrumen penelitian adalah alat yang digunakan oleh peneliti dalam mengumpulkan data. Kualitas instrumen sebagai alat pengambil data harus teruji kelayakannya dari segi validitas, reliabilitas, daya pembeda dan tingkat kesukaran.

a. Validitas Butir Soal

Validitas tes yang digunakan adalah validitas isi (content validity). Validitas isi pada umumnya ditentukan melalui 
pertimbangan para ahli. Untuk memberikan gambaran bagaimana suatu tes divalidasi dengan menggunakan validitasi isi, pertimbangan para ahli tersebut dilakukan dengan cara para ahli diminta untuk mengamati secara cermat semua item dalam tes yang hendak divalidasi, kemudian meminta untuk mengoreksi semua item-item yang telah dibuat, dan pada akhir perbaikan para ahli juga diminta untuk memberikan pertimbangan tentang bagaimana suatu tes tersebut menggambarkan cakupan isi yang hendak diukur.

b. Reliabilitas Tes

Pengujian reliabilitas instrumen dilakukan secara eksternal dengan test-retest. Instrumen diuji dengan test-retest dilakukan dengan cara mengujicobakan instrumen beberapa kali pada responden yang sama. Jadi dalam hal ini instrumennya sama, respondennya sama akan tetapi waktunya berbeda. Reliabilitas diukur dari koefisien korelasi antara percobaan pertama dengan yang berikutnya. Bila koefisien korelasi positif dan signifikan maka instrumen tersebut dinyatakan reliable (Sugiyono, 2009). Teknik yang digunakan untuk menentukan reliabilitas tes adalah dengan teknik korelasi product moment angka kasar:
$r_{X Y}=\frac{N \sum X Y-\left(\sum X\right)\left(\sum Y\right)}{\sqrt{\left\{N \sum X^{2}-\left(\sum X^{2}\right)\right\}\left\{N \sum Y^{2}-\left(\sum Y\right)^{2}\right\}}}$

(Sugiyono, 2009)

Keterangan:

$\mathrm{r}_{\mathrm{XY}}=$ koefisien korelasi

$\mathrm{X}=$ skor rata-rata tes pertama

$\mathrm{Y}=$ skor rata-rata tes kedua

$\mathrm{N}=$ jumlah subyek

Tabel 3.3 Interval Reliabilitas

\begin{tabular}{|c|c|l|}
\hline No & Interval $\mathrm{r}_{11}$ & \multicolumn{1}{|c|}{ Kriteria } \\
\hline 1 & $0,00<\mathrm{r}_{11} \leq 0,20$ & Sangat rendah \\
\hline 2 & $0,20<\mathrm{r}_{11} \leq 0,40$ & Rendah \\
\hline 3 & $0,40<\mathrm{r}_{11} \leq 0,60$ & Cukup \\
\hline 4 & $0,60<\mathrm{r}_{11} \leq 0,80$ & Tinggi \\
\hline 5 & $0,80<\mathrm{r}_{11}<0,10$ & Sangat tinggi \\
\hline
\end{tabular}

(Arikunto, 2007)

\section{c. Tingkat Kemudahan Soal}

Tingkat kemudahan adalah bilangan yang menunjukkan sukar atau mudahnya suatu soal. Untuk menghitung tingkat kemudahan tiap butir soal digunakan persamaan:

$P=\frac{B}{J S} \ldots \ldots \ldots$ (Arikunto, 2007)

Keterangan:

$P=$ indeks kemudahan.

$B$ = banyaknya mahasiswa yang menjawab soal itu dengan benar.

$J S=$ jumlah seluruh mahasiswa peserta tes. 
Nilai $P$ yang diperoleh dapat diinterpretasikan untuk menentukan tingkat kemudahan butir soal dengan menggunakan kriteria pada tabel di bawah ini.

Tabel 3.4 Interpretasi Tingkat Kemudahan Butir Soal

\begin{tabular}{|c|c|}
\hline Nilai $\boldsymbol{P}$ & Kriteria \\
\hline $0,00-0,30$ & Sukar \\
\hline $0,31-0,70$ & Sedang \\
\hline $0,71-1,00$ & Mudah \\
\hline
\end{tabular}

(Arikunto, 2007)

\section{d. Daya Pembeda Soal}

Untuk menentukan nilai daya pembeda maka digunakan rumus sebagai berikut:

$$
D P=\frac{B_{A}}{J_{A}}-\frac{B_{B}}{J_{B}}=P_{A}-P_{B}
$$

(Arikunto, 2007)

Keterangan:

$D P=$ daya pembeda butir soal.

$B_{A}=$ banyak peserta kelompok atas yang menjawab soal itu dengan benar.

$B_{B}=$ banyak peserta kelompok bawah

yang menjawab soal itu dengan benar.

$J_{A}=$ banyaknya peserta kelompok atas.

$J_{B}=$ banyaknya peserta kelompok bawah.

Nilai $D P$ yang diperoleh dapat diinterpretasikan untuk menentukan daya pembeda butir soal dengan menggunakan kriteria pada tabel di bawah ini.

\section{Tabel 3.5 Interpretasi Daya Pembeda Butir Soal}

\begin{tabular}{|l|l|}
\hline \multicolumn{1}{|c|}{ Nilai $\boldsymbol{D P}$} & \multicolumn{1}{c|}{ Kriteria } \\
\hline Negatif & Soal Dibuang \\
\hline $0,00-0,20$ & Jelek \\
\hline $0,21-0,40$ & Cukup \\
\hline $0,41-0,70$ & Baik \\
\hline $0,71-1,00$ & Baik Sekali \\
\hline
\end{tabular}

(Arikunto, 2007)

Teknik Pengolahan Data

a. Melakukan penskoran untuk kemampuan kognitif dan keterampilan berfikir kreatif

Penskoran hasil tes kemampuan mahasiswa menggunakan aturan penskoran untuk tes pilihan ganda yaitu 1 atau 0. Skor satu jika jawaban tepat, dan skor 0 jika jawaban salah. Skor maksimum ideal sama dengan jumlah soal yang diberikan.

b. Analisis Data Instrumen

1) Perhitungan Gain yang dinormalisasi

Gain adalah selisih antara skor pretest dengan posttest. "Perbedaan skor pretest dan posttest ini diasumsikan sebagai efek dari treatment" (Panggabean, 2001). Gain ternormalisasi merupakan perbandingan antara skor gain yang diperoleh mahasiswa 
dengan skor gain maksimum yang dapat diperoleh (Hake, 1998), secara matematis dapat dituliskan sebagai berikut:

$$
<\mathrm{g}>=\frac{\mathrm{S}_{\text {post }}-\mathrm{S}_{\text {pre }}}{\mathrm{S}_{\text {maks }}-\mathrm{S}_{\text {pre }}}
$$

(Hake, 1998)

a) Menentukan nilai rata-rata (mean) dari skor gain ternormalisasi

b) Mengintrepetasikan skor ratarata gain ternormalisasi dengan menggunakan tabel di bawah ini.

Tabel 3.6 Interpretasi Skor RataRata Gain Ternormalisasi

\begin{tabular}{|c|c|}
\hline Nilai $<\mathrm{g}>$ & Efektifitas \\
\hline $0,00<<\mathrm{g}>\leq 0,30$ & Rendah \\
\hline $0,30<<\mathrm{g}>\leq 0,70$ & Sedang \\
\hline $0,70<<\mathrm{g}>\leq 1,00$ & Tinggi \\
\hline
\end{tabular}

(Hake, 1998)

\section{2) Uji Hipotesis}

Pengujian hipotesis dalam penelitian ini menggunakan uji-t satu ekor (one tile) dengan taraf signifikansi $\alpha=0,05$. Jika data berdistribusi normal dan homogen maka digunakan uji statistik dengan rumus :

$$
t=\frac{\bar{x}-\bar{y}}{\left(\frac{\left(n_{x}-1\right) S_{x}^{2}+\left(n_{y}-1\right) S_{y}^{2}}{n_{x}+n_{y}-2}\right)\left(\frac{1}{n_{x}}+\frac{1}{n_{y}}\right)}
$$

(Uyanto, 2009:93)
Keterangan :

$\bar{x}=$ rata-rata gain kelompok eksperimen.

$\bar{y}=$ rata-rata gain kelompok kontrol.

$n_{x}=$ jumlah sampel kelompok eksperimen.

$n_{y}=$ jumlah sampel kelompok kontrol.

$\mathrm{S}_{\mathrm{x}}=$ varians kelompok eksperimen.

$\mathrm{S}_{\mathrm{y}}=$ varians kelompok eksperimen.

Kriteria pengujian dengan membandingkan taraf signifikansi hitungan $\mathrm{P}$ dengan $\alpha=0,05$, jika taraf signifikansi hitungan lebih kecil dari 0,05, maka $\mathrm{H}_{\mathrm{a}}$ diterima atau dengan membandingkan $t_{\text {hitung }}>t_{\text {tabel }}$. Maka $\mathrm{H}_{\mathrm{a}}$ diterima pada taraf signifikansi $\alpha=$ 0,05 .

3) Skala Sikap Mahasiswa

Data yang diperoleh dari skala sikap mahasiswa dapat dihitung persentasenya dengan menggunakan rumus sebagai berikut :

$$
T=\frac{J}{N} \times 100 \%
$$

Keterangan :

$\mathrm{T}$ : Persentase tanggapan terhadap setiap pernyataan.

J : Jumlah jawaban setiap kelompok pernyataan.

$\mathrm{N}$ : Jumlah mahasiswa. 
Tabel 3.7. Kriteria Skala Sikap Mahasiswa

\begin{tabular}{|l|l|}
\hline \multicolumn{1}{|c|}{ SS (\%) } & \multicolumn{1}{c|}{ Kriteria } \\
\hline $\mathrm{SS}=0$ & Tak satu mahasiswa pun \\
$0<\mathrm{SS}<25$ & Sebagian kecil mahasiswa \\
$25 \leq \mathrm{SS}<50$ & Hampir setengah mahasiswa \\
$\mathrm{SS}=50$ & Setengah mahasiswa \\
$50<\mathrm{SS}<75$ & Sebagian besar mahasiswa \\
$75 \leq \mathrm{SS}<100$ & Hampir seluruh mahasiswa \\
$\mathrm{SS}=100$ & Seluruh mahasiswa \\
\hline
\end{tabular}

4) Lembar Observasi

Menganalisis lembar observasi untuk memperoleh deskripsi keterlaksanaan pembelajaran sinektik dengan penugasan mind mapping. Tingkat keterlaksanaan pembelajaran dapat dihitung dengan persamaan sebagai berikut:

\%Keterlaksanaan $=\frac{\text { jumlah aspek yang diamati terlaksana }}{\text { jumlah keseluruhan aspek yang akan diamati }} \times 100 \%$

Tabel 3.8. Kriteria Skala Sikap Mahasiswa

\begin{tabular}{|c|l|}
\hline SS $(\%)$ & \multicolumn{1}{|c|}{ Kriteria } \\
\hline $\mathrm{SS}=0$ & Tak satu kegiatan pun \\
$0<\mathrm{SS}<25$ & Sebagian kecil kegiatan \\
$25 \leq \mathrm{SS}<50$ & Hampir setengah kegiatan \\
$\mathrm{SS}=50$ & Setengah kegiatan \\
$50<\mathrm{SS}<75$ & Sebagian besar kegiatan \\
$75 \leq \mathrm{SS}<100$ & Hampir seluruh kegiatan \\
$\mathrm{SS}=100$ & Seluruh kegiatan \\
\hline
\end{tabular}

\section{HASIL DAN PEMBAHASAN}

Pada bagian ini, dipaparkan hasil temuan berupa data penelitian yang diperoleh selama melakukan penelitian serta pembahasan yang terkait dengan hasil penelitian.
1. Kemampuan Kognitif Mahasiswa

a. Data Kemampuan Kognitif Mahasiswa secara Umum

Skor rata-rata tes awal, tes akhir, dan gain yang dinormalisasi kemampuan kognitif pada materi listrik untuk mahasiswa yang mendapatkan pembelajaran inductive thinking berbasis keterampilan proses sains dan mahasiswa yang mendapatkan pembelajaran pembelajaran inductive thinking menunjukkan bahwa rata-rata nilai tes awal kelas eksperimen sebesar 29,69.; kelas kontrol sebesar 31,81; rata-rata nilai tes akhir kelas eksperimen 68,75 , kelas kontrol sebesar 63,06; N-gain kelas eksperimen sebesar 55\%; dan $\mathrm{N}$-gain kelas kontrol sebesar $46 \%$.

b. Deskripsi

Peningkatan

Kemampuan Kognitif pada Materi Listrik berdasarkan setiap Ranah Kognitif

Perbandingan rata-rata $\mathrm{N}$-gain kemampuan kognitif mahasiswa untuk masing-masing ranah kognitif tersebut pada kelas eksperimen dan kelas kontrol terlihat rata-rata $\mathrm{N}$-gain untuk tiap domain kognitif Bloom pada kelas eksperimen dan kelas kontrol. N-Gain pada aspek mengingat (C1) untuk kelas eksperimen 1 sebesar 65 dan 52 untuk kelas eksperimen 2.

Kedua nilai $\mathrm{N}$-gain kedua kelas tersebut dalam kategori sedang, tetapi perbedaan nilai N-gain yang diperoleh menunjukkan bahwa hasil belajar mahasiswa pada aspek 
mengingat (C1) pada kelas eksperimen lebih tinggi dibandingkan dengan kelas kontrol. Sejalan dengan itu, untuk hasil belajar mahasiswa pada aspek pemahaman (C2) pada kelas eksperimen lebih besar dibandingkan dengan kelas kontrol. Hal tersebut terlihat dari nilai $\mathrm{N}$-gain yang diperoleh, yaitu untuk kelas eksperimen sebesar 49 dan kelas kontrol sebesar 41 (dua-duanya masih dalam kategori sedang), dengan kata lain, dapat dikatakan bahwa mahasiswa yang mendapatkan pembelajaran inductive thinking berbasis keterampilan proses sains lebih baik dalam aspek pemahaman (C2) dibandingkan dengan mahasiswa yang mendapatkan pembelajaran inductive thinking. Hasil belajar mahasiswa pada aspek kognitif pemahaman (C2) dapat terlatih melalui kegiatan praktikum.

Kemampuan

pengaplikasian

konsep

rata-rata

mahasiswa pada kelas eksperimen sebesar 53 dan pada kelas kontrol sebesar 47. Kedua nilai N-gain yang diperoleh tersebut sama-sama masuk dalam kategori sedang, tetapi perbedaan nilai $\mathrm{N}$-gain antara kedua kelas menunjukkan bahwa mahasiswa yang memperoleh model pembelajaran inductive thinking berbasis keterampilan proses sains lebih baik dalam pengaplikasian konsep dibandingkan dengan mahasiswa yang memperoleh model pembelajaran inductive thinking.
Aplikasi konsep (C3) dapat terlatih melalui kegiatan praktikum dan kegiatan diskusi.

\section{Kemampuan Berpikir Kreatif}

a. Data Hasil Tes Berpikir Kreatif

Keterampilan berfikir kreatif mahasiswa dinilai dari hasil pre-test yang diberikan sebelum perkuliahan dan post-test setelah mengikuti perkuliahan. Indikator keterampilan berfikir kreatif yang dinilai meliputi: kemampuan memberikan banyak gagasan, jawaban, penyelesaian masalah; kemampuan mencari banyak alternatif yang berbeda; selalu memikirkan lebih dari satu jawaban; mampu melahirkan ungkapan yang baru; mampu membuat kombinasi yang tidak lazim; mampu memperkaya dan mengembangkan gagasan. Data skor rerata tes awal dan tes akhir untuk berfikir kreatif mahasiswa terhadap konsep rangkaian listrik arus searah untuk Kelompok Eksperimen dan Kelompok Kontrol dari masing-masing indikator keterampilan berfikir kreatif disajikan dalam uraian berikut.

b. Data Hasil Tes Berpikir Kreatif: Kemampuan Memberikan Banyak Gagasan, Jawaban dan Penyelesaian Masalah

Berdasarkan penelitian yang telah dilakukan diperoleh data tentang peningkatan keterampilan berfikir kreatif mahasiswa untuk Kelompok Eksperimen dan Kelompok Kontrol 
dari indikator kemampuan memberikan banyak gagasan, jawaban dan penyelesaian masalah dapat dilihat bahwa $\mathrm{N}$-gain untuk Kelompok Eksperimen adalah 42,6\% dan N-gain untuk Kelompok Kontrol sebesar 36,3\%. N-gain untuk kedua kelompok tersebut berada pada kategori sedang. Untuk mengetahui adanya perbedaan secara signifikan $\mathrm{N}$-gain antara kedua kelompok, dilakukan uji hipotesis. Berdasarkan karakteristik populasi dan teknik penarikan sampel penelitian maka peneliti tidak dapat mengasumsikan bahwa populasi berdistribusi normal dan homogen. Dengan demikian pengujian hipotesis menggunakan analisis statistik non-parametrik. Untuk menguji hipotesis tentang komponen berfikir kreatif digunakan uji U Mann- Withney seperti pada Lampiran.

Berdasarkan perhitungan pada Lampiran, $\mathrm{Z}_{\text {hitung }}=-0,670$ dan $\mathrm{z}_{\text {kritis }}$ untuk uji satu ekor dengan taraf signifikansi 0,05 (harga $z$ untuk daerah di bawah area 0,05) adalah 1,645. Hal ini menunjukkan bahwa $Z_{\text {hitung }}>Z_{\text {kritis }}$ atau $Z_{\text {hitung }}$ berada di area penerimaan Ho, yang berarti bahwa hipotesis nol (Ho) diterima dan hipotesis alternatif $\left(\mathrm{H}_{\mathrm{A}}\right)$ ditolak. Dapat disimpulkan bahwa tidak terdapat perbedaan secara signifikan antara Kelompok Eksperimen dan Kelompok Kontrol terhadap komponen kemampuan memberikan gagasan, jawaban dan penyelesaian masalah.
Analisis U Mann-Withney tersebut menyatakan bahwa komponen berpikir kreatif tentang kemampuan memberikan gagasan, jawaban dan penyelesaian masalah untuk Kelompok Eksperimen dan Kelompok Kontrol adalah sama.

c. Data Hasil Tes Berpikir Kreatif: Kemampuan Mencari Banyak Alternatif yang Berbeda

Data pre-test dan post-test dari komponen kemampuan berfikir kreatrif mahasiswa untuk Kelompok Eksperimen dan Kelompok Kontrol untuk indikator kemampuan mahasiswa dalam mencari alternatif yang berbeda, menunjukkan bahwa $\mathrm{N}$-gain untuk Kelompok Eksperimen adalah $31,7 \%$ yang berada pada kategori sedang dan untuk Kelompok Kontrol nilai $\mathrm{N}$-gainnya adalah 5,3\% yang berada pada kategori rendah. Untuk mengetahui ada tidaknya perbedaan yang signifikan peningkatan indikator kemampuan mahasiswa mencari alternatif yang berbeda, dilakukan uji hipotesis dengan menggunakan uji U-MannWithney seperti pada Lampiran.

Berdasarkan perhitungan pada Lampiran, $\mathrm{Z}_{\text {hitung }}=-3,704$ dan $\mathrm{Z}_{\text {kritis }}$ untuk uji satu ekor dengan taraf signifikansi 0,05 (harga $z$ untuk daerah di bawah area 0,05) adalah 1,645. Hal ini menunjukkan bahwa $\mathrm{Z}_{\text {hitung }}<\mathrm{Z}_{\text {kritis }}$ atau $\mathrm{Z}_{\text {hitung }}$ berada di area penolakan Ho yang berarti bahwa hipotesis nol (Ho) ditolak dan hipotesis alternatif $\left(\mathrm{H}_{\mathrm{A}}\right)$ diterima. 
Sehingga dapat disimpulkan bahwa terdapat perbedaan secara signifikan antara Kelompok Eksperimen dan Kelompok Kontrol terhadap komponen kemampuan mencari banyak alternatif yang berbeda. Analisis U Mann-Withney tersebut menyatakan bahwa komponen berpikir kreatif tentang kemampuan mencari banyak alternatif yang berbeda untuk kelompok eskperimen lebih tinggi dibandingkan dengan Kelompok Kontrol.

d. Data Hasil Tes Berpikir Kreatif: Selalu Memikirkan Lebih dari Satu Jawaban

Deskripsi kemampuan berfikir kreatif mahasiswa untuk indikator selalu memikirkan lebih dari satu jawaban, sebelum dan sesudah perkuliahan dapat dilihat dari peningkatan perolehan rerata skor post-test terhadap rerata pre-test, seperti yang terdapat pada Gambar 4.5 .

Berdasarkan Gambar 4.5, Ngain untuk Kelompok Eksperimen sebesar 21,2\% sedangkan N-gain untuk Kelompok Kontrol sebesar 5,6\%. Untuk melihat adanya perbedaann $\mathrm{N}$-gain kedua kelompok maka dilakukan uji hipotesis dengan menggunakan uji U Mann-Whitney seperti pada Lampiran E. Dari hasil perhitungan pada Lampiran diperoleh $Z_{\text {hitung }}=-2,840$ dan $Z_{\text {kritis }}$ untuk uji satu ekor dengan taraf signifikansi 0,05 (harga $z$ untuk daerah di bawah area 0,05) adalah -1,645. Hal ini menunjukkan bahwa $\mathrm{Z}_{\text {hitung }}<\mathrm{Z}_{\text {kritis }}$ atau $Z_{\text {hitung }}$ berada di area penolakan Ho yang berarti bahwa hipotesis nol (Ho) diolak dan hipotesis alternatif $\left(\mathrm{H}_{\mathrm{A}}\right)$ diterima.

Dapat disimpulkan bahwa terdapat perbedaan secara signifikan antara Kelompok Eksperimen dan Kelompok Kontrol terhadap komponen kemampuan untuk selalu memikirkan lebih dari satu jawaban. Analisis tersebut menyatakan bahwa komponen berpikir kreatif tentang kemampuan untuk selalu memikirkan lebih dari satu jawaban bagi Kelompok Eksperimen lebih tinggi dibandingkan dengan Kelompok Kontrol.

e. Data Hasil Tes Berpikir Kreatif: Mampu Melahirkan Ungkapan yang Baru

Data skor rerata tes awal, tes akhir serta $\mathrm{N}$-gain soal keterampilan berfikir kreatif mahasiswa untuk komponen mampu melahirkan ungkapan yang baru terhadap materi rangkaian listrik arus searah untuk Kelompok Eksperimen dan Kelompok Kontrol digambarkan pada Gambar 4.6.

Dari data pada Gambar 4.6, besar N-gain untuk Kelompok Eksperimen adalah 37,6\% sedangkan untuk Kelompok Kontrol N-gainnya adalah 24,1\%. Berdasarkan kriteria $\mathrm{N}$-gain, N-gain untuk Kelompok Eksperimen berada pada kategori sedang dan $\mathrm{N}$-gain untuk Kelompok Kontrol berada pada kategori rendah. 
Untuk melihat adanya perbedaan $\mathrm{N}$ gain kedua kelompok maka dilakukan uji hipotesis dengan menggunakan uji U Mann-Whitney seperti pada Lampiran .

Berdasarkan perhitungan pada Lampiran diperoleh $\mathrm{Z}_{\text {hitung }}=-2,190$ dan $Z_{\text {kritis }}$ untuk uji satu ekor dengan taraf signifikansi 0,05 (harga $z$ untuk daerah di bawah area 0,05) adalah 1,645. Hal ini menunjukkan bahwa $\mathrm{Z}_{\text {hitung }}<\mathrm{Z}_{\text {kritis }}$ atau $\mathrm{Z}_{\text {hitung }}$ berada di area penolakan Ho yang berarti bahwa hipotesis nol (Ho) diolak dan hipotesis alternatif $\left(\mathrm{H}_{\mathrm{A}}\right)$ diterima.

Sehingga dapat disimpulkan bahwa terdapat perbedaan secara signifikan antara Kelompok Eksperimen dan Kelompok Kontrol terhadap komponen kemampuan mahasiswa untuk melahirkan ungkapan yang baru. Analisis ini juga menunjukkan bahwa peningkatan kemampuan berfikir kreatif untuk komponen mampu melahirkan ungkapan yang baru bagi mahasiswa Kelompok Eksperimen lebih tinggi daripada Kelompok Kontrol.

f. Data Hasil Tes Berpikir Kreatif: Mampu Membuat Kombinasi yang Tidak Lazim

Deskripsi kemampuan berfikir kreatif mahasiswa untuk indikator mampu membuat kombinasi yang tidak lazim, sebelum dan sesudah perkuliahan dapat dilihat dari peningkatan perolehan rerata skor post-test terhadap rerata pre-test.
Eksperimen adalah 14,3\% sedangkan untuk Kelompok Kontrol $\mathrm{N}$-gainnya adalah $8,3 \%$. Berdasarkan kriteria $\mathrm{N}$-gain yang dinormalisasi, $\mathrm{N}$ gain untuk Kelompok Eksperimen dan Kelompok Kontrol berada pada kategori rendah. Untuk melihat adanya perbedaann N-gain kedua kelompok maka dilakukan uji hipotesis dengan menggunakan uji UMann whitney seperti pada Lampiran.

Berdasarkan perhitungan pada Lampiran diperoleh $\mathrm{Z}_{\text {hitung }}=-1,820$ dan $Z_{\text {kritis }}$ untuk uji satu ekor dengan taraf signifikansi 0,05 (harga $z$ untuk daerah di bawah area 0,05) adalah 1,645. Hal ini menunjukkan bahwa $Z_{\text {hitung }}<Z_{\text {kritis }}$ atau $Z_{\text {hitung }}$ berada di area penolakan Ho yang berarti bahwa hipotesis nol (Ho) diolak dan hipotesis alternatif $\left(\mathrm{H}_{\mathrm{A}}\right)$ diterima.

Sehingga dapat disimpulkan bahwa terdapat perbedaan secara signifikan antara Kelompok Eksperimen dan Kelompok Kontrol terhadap komponen kemampuan membuat kombinasi yang tidak lazim. Analisis ini juga menunjukkan bahwa peningkatan kemampuan berfikir kreatif untuk komponen membuat kombinasi yang tidak lazim bagi mahasiswa Kelompok Eksperimen tidak lebih tinggi daripada Kelompok Kontrol.

g. Mampu Memperkaya dan Mengembangkan Gagasan

Deskripsi kemampuan berfikirkreatif mahasiswa untuk indikator mampu memperkaya dan 
mengembangkan gagasan, sebelum dan sesudah perkuliahan dapat dilihat dari peningkatan perolehan rerata skor post-test terhadap rerata pre-test, seperti yang terdapat pada Gambar 4.8 .

Berdasarkan data pada Gambar 4.8 memperlihatkan besar Ngain untuk Kelompok Eksperimen adalah 28,0\% sedangkan untuk Kelompok Kontrol N-gainnya adalah $8,2 \%$. Untuk melihat adanya perbedaan $\mathrm{N}$-gain kedua kelompok maka dilakukan uji hipotesis dengan menggunakan uji U Mann-withney

Berdasarkan perhitungan pada Lampiran diperoleh $\mathrm{Z}_{\text {hitung }}=-3,110$ dan $Z_{\text {kritis }}$ untuk uji satu ekor dengan taraf signifikansi 0,05 (harga $z$ untuk daerah di bawah area 0,05) adalah 1,645. Hal ini menunjukkan bahwa $z_{\text {hitung }}<z_{\text {kritis }}$ atau $z_{\text {hitung }}$ berada di area penolakan Ho yang berarti bahwa hipotesis nol (Ho) diolak dan hipotesis alternatif $\left(\mathrm{H}_{\mathrm{A}}\right)$ diterima. Sehingga dapat disimpulkan bahwa terdapat perbedaan secara signifikan antara Kelompok Eksperimen dan Kelompok Kontrol terhadap komponen kemampuan memperkaya dan mengembangkan gagasan.

Analisis ini juga menunjukkan bahwa peningkatan kemampuan berfikir kreatif untuk komponen memperkaya dan mengembangkan gagasan bagi mahasiswa Kelompok Eksperimen lebih tinggi daripada Kelompok Kontrol. h. Analisis Gabungan Komponen Berfikir Kreatif

Gambaran skor pre-test, skor post-test dan N-gain untuk seluruh komponen berfikir kreatif disajikan pada Gambar 4.9, sedangkan perolehan $\mathrm{N}$-gain secara keseluruhan dari komponen berfikir kreatif, $\mathrm{N}$ gain gabungan untuk semua komponen berfikir kreatif bagi Kelompok Eksperimen adalah 31,6\% sedangkan untuk Kelompok Kontrol $\mathrm{N}$-gain yang dihasilkan sebesar 16,6\%. Jika dilihat dari kategori Ngain, Kelompok Eksperimen termasuk kategori sedang dan Kelompok Kontrol termasuk kategori rendah. Untuk mengetahui perbandingan $\mathrm{N}$-gain kemampuan berfikir kreatif dari kedua kelompok maka dilakukan uji hipotesis dengan menggunakan uji U Mann- Withney seperti pada Lampiran.

Dari hasil perhitungan pada Lampiran diperoleh $\mathrm{Z}_{\text {hitung }}=-4,660$ dan $Z_{\text {kritis }}$ untuk uji satu ekor dengan taraf signifikansi 0,05 (harga $z$ untuk daerah di bawah area 0,05) adalah 1,645. Hal ini menunjukkan bahwa $Z_{\text {hitung }}<z_{\text {kritis }}$ atau $Z_{\text {hitung }}$ berada di area penolakan Ho yang berarti bahwa hipotesis nol (Ho) ditolak dan hipotesis alternatif $\left(\mathrm{H}_{\mathrm{A}}\right)$ diterima.

Kesimpulannya, terdapat perbedaan yang signifikan antara Kelompok Eksperimen dan Kelompok Kontrol dalam berfikir kreatif. Analisis ini juga menunjukkan bahwa kemampuan 
berfikir kreatif mahasiswa Kelompok Kelompok Kontrol. Eksperimen lebih tinggi daripada

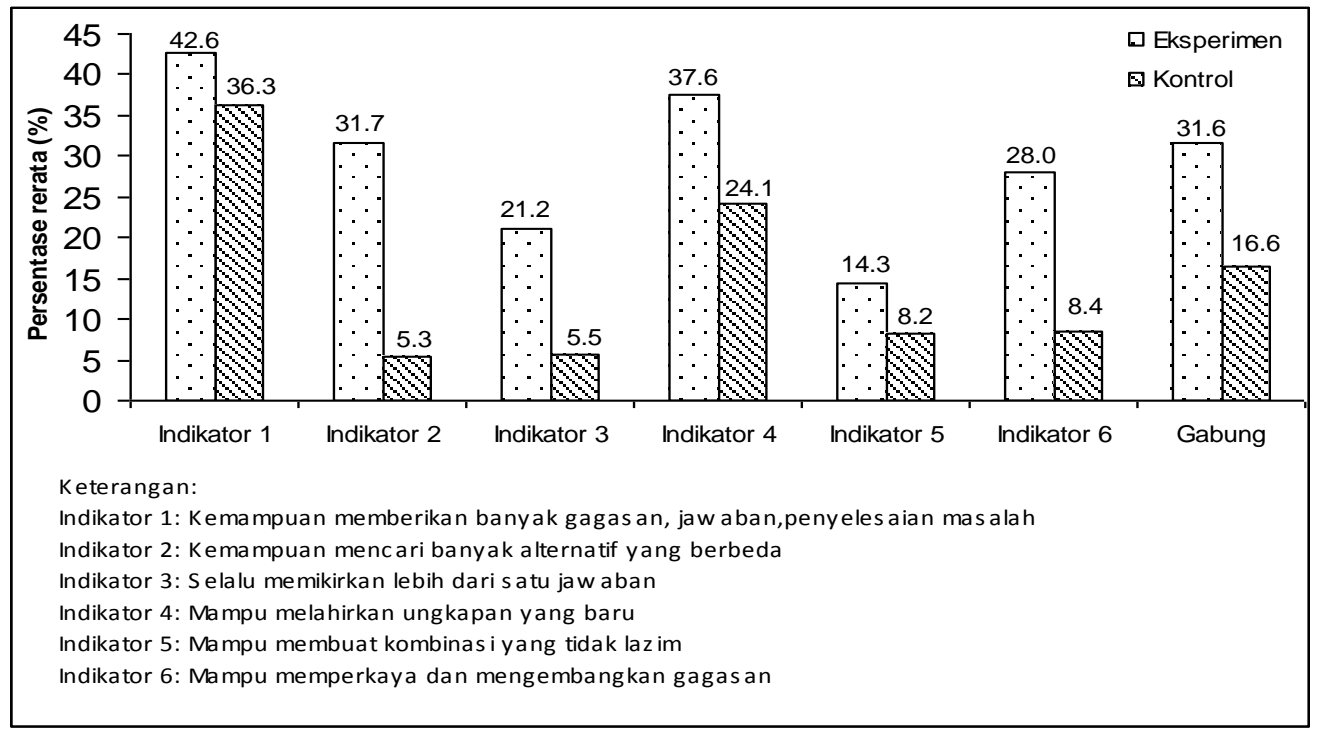

Gambar 4.10 Histogram N-Gain Seluruh Komponen Keterampilan Berfikir Kreatif

\section{i. Pelaksanaan}

Pembelajaran

Selama kegiatan penelitian dilakukan yang menjadi dosen adalah peneliti, sedangkan yang menjadi observer kegiatan dosen dan mahasiswa adalah dua orang dosen IPA. Observasi dilakukan untuk memberikan gambaran pelaksanaan proses pembelajaran sesuai dengan yang direncanakan.

1) Observasi Kegiatan Mahasiswa

Selama Pembelajaran

a) Observasi Kegiatan Mahasiswa Selama pembelajaran inductive thinking berbasis keterampilan proses sains

Berdasarkan hasil observasi kegiatan mahasiswa yang dilakukan terhadap proses pembelajaran pada pembelajaran inductive thinking berbasis keterampilan proses sains, didapatkan hasil sebagai berikut:

Tabel 4.1. Persentas Keterlaksanaan Model Pembelajaran Inductive Thinking Berbasis Keterampilan Proses Sains Oleh Mahasiswa

\begin{tabular}{|c|c|c|}
\hline Pertemuan & $\begin{array}{c}\text { Persentase } \\
\text { Keterlaksanaan } \\
(\%)\end{array}$ & Kriteria \\
\hline 1 & 100 & $\begin{array}{c}\text { Seluruh kegiatan } \\
\text { terlaksana }\end{array}$ \\
\hline 2 & 100 & $\begin{array}{c}\text { Seluruh kegiatan } \\
\text { terlaksana }\end{array}$ \\
\hline 3 & 100 & $\begin{array}{c}\text { Seluruh kegiatan } \\
\text { terlaksana }\end{array}$ \\
\hline
\end{tabular}

Dari tabel 4.1 di atas, terlihat bahwa kegiatan mahasiswa selama proses pembelajaran sudah sesuai dengan model pembelajaran yang 
direncanakan yaitu model pembelajaran inductive thinking berbasis keterampilan proses sains.

b) Observasi Kegiatan Mahasiswa selama Pembelajaran Inductive Thinking

Berdasarkan hasil kegiatan mahasiswa yang dilakukan terhadap proses pembelajaran pada kelas kontrol, didapatkan hasil sebagai berikut:

Tabel 4.2. Persentase Keterlaksanaan Model Pembelajaran Kooperatif NHT oleh Mahasiswa

\begin{tabular}{|c|c|c|}
\hline Pertemuan & $\begin{array}{c}\text { Persentase } \\
\text { Keterlaksanaan } \\
(\%)\end{array}$ & Kriteria \\
\hline 1 & 100 & $\begin{array}{c}\text { Seluruh } \\
\text { kegiatan } \\
\text { terlaksana } \\
\text { Seluruh } \\
\text { kegiatan } \\
\text { terlaksana } \\
\text { Seluruh } \\
\text { kegiatan } \\
\text { terlaksana }\end{array}$ \\
\hline
\end{tabular}

Dari tabel 4.2 di atas, terlihat bahwa kegiatan mahasiswa selama proses pembelajaran sudah sesuai dengan model pembelajaran yang direncanakan yaitu model pembelajaran inductive thinking.

2) Observasi Pembelajaran yang dilaksanakan Dosen

a) Hasil Observasi Kegiatan Dosen Selama pembelajaran inductive thinking berbasis keterampilan proses sains
Berdasarkan hasil observasi kegiatan dosen yang dilakukan terhadap proses pembelajaran pada kedua kelas penelitian, didapatkan hasil sebagai berikut:

Tabel 4.3. Persentase Keterlaksanaan Model Pembelajaran Inductive Thinking Berbasis Keterampilan Proses Sains Oleh Dosen

\begin{tabular}{|c|c|c|}
\hline Pertemuan & $\begin{array}{c}\text { Persentase } \\
\text { Keterlaksanaan } \\
(\%)\end{array}$ & Kriteria \\
\hline 1 & 100 & $\begin{array}{c}\text { Seluruh kegiatan } \\
\text { terlaksana }\end{array}$ \\
2 & 100 & $\begin{array}{c}\text { Seluruh kegiatan } \\
\text { terlaksana } \\
\text { Seluruh kegiatan } \\
\text { terlaksana }\end{array}$ \\
\hline
\end{tabular}

Tabel 4.3 di atas menunjukkan bahwa dosen telah melakukan langkah-langkah pembelajaran seperti yang direncanakan, yaitu penerapan model pembelajaran inductive thinking berbasis keterampilan proses sains. Hal tersebut terlihat dari kegiatan dosen yang terpantau dari lembar keterlaksanaan yang disesuaikan dengan model pembelajaran inductive thinking berbasis keterampilan proses sains.

b) Hasil Observasi Kegiatan Dosen selama Pembelajaran inductive thinking berbasis keterampilan proses sains

Berdasarkan hasil observasi kegiatan mahasiswa yang dilakukan selama proses pembelajaran pada 
kelas kooperatif NHT, didapatkan hasil seperti yang tertera dalam tabel 4.4 berikut ini:

Tabel 4.4. Persentase Keterlaksanaan Model Pembelajaran Inductive Thinking Berbasis Keterampilan Proses Sains Oleh Dosen

\begin{tabular}{|c|c|c|}
\hline Pertemuan & $\begin{array}{c}\text { Persentase } \\
\text { Keterlaksanaan } \\
(\%)\end{array}$ & Kriteria \\
\hline 1 & 100 & $\begin{array}{c}\text { Seluruh } \\
\text { kegiatan } \\
\text { terlaksana } \\
\text { Seluruh } \\
\text { kegiatan } \\
\text { terlaksana } \\
\text { Seluruh } \\
\text { kegiatan } \\
\text { terlaksana }\end{array}$ \\
\hline
\end{tabular}

Tabel 4.4 di atas menunjukkan bahwa dosen telah melakukan langkah-langkah pembelajaran seperti yang direncanakan, yaitu penerapan model pembelajaran inductive thinking. Hal tersebut terlihat dari kegiatan dosen yang terpantau dari lembar keterlaksanaan yang disesuaikan dengan model pembelajaran inductive thinking.

3) Tanggapan Mahasiswa dan Dosen terhadap Model Pembelajaran yang diterapkan
a) Tanggapan
Mahasiswa
terhadap Model Pembelajaran yang diterapkan

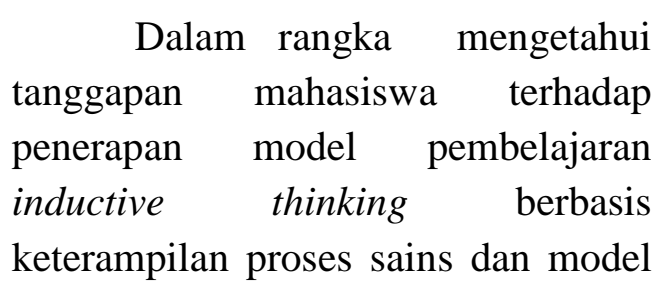

pembelajaran inductive thinking, maka digunakan instrumen Angket. Angket yang digunakan dalam penelitian ini terdiri dari 16 buah pernyataan dengan 4 kategori skor tanggapan.

b) Tanggapan Mahasiswa terhadap Model Pembelajaran inductive thinking berbasis keterampilan proses sains

Untuk mengetahui tanggapan mahasiswa terhadap model pembelajaran inductive thinking berbasis keterampilan proses sains, diberikan angket kepada mahasiswa. adapun tanggapan mahasiswa dapat terlihat dalam lampiran.

Angket yang diberikan kepada mahasiswa terdiri dari empat substansi pernyataan, yaitu: model pembelajaran inductive thinking berbasis keterampilan proses sains merupakan model belajar yang baru dan cocok diterapkan dalam belajar IPA di kelas bagi mahasiswa, model pembelajaran inductive thinking dapat membuat mahasiswa lebih termotivasi dalam pembelajaran, mengurangi kejenuhan mahasiswa dalam belajar di kelas, model pembelajaran inductive thinking berbasis keterampilan proses sains membantu mahasiswa untuk menguasai konsepkonsep IPA, model pembelajaran inductive thinking berbasis keterampilan proses sains membuat mahasiswa terlatih mengemukakan ide-ide dalam mengembangkan kemampuan berpikir kreatif 
mahasiswa, mahasiswa juga menyatakan setuju bahwa model pembelajaran inductive thinking berbasis keterampilan proses sains dapat membuat mahasiswa lebih termotivasi dalam pembelajaran (76\%), mahasiswa setuju model pembelajaran inductive thinking berbasis keterampilan proses sains membantu mahasiswa untuk menguasai konsep-konsep IPA (81\%), dan sebanyak mahasiswa setuju bahwa model pembelajaran inductive thinking berbasis keterampilan proses sains membuat mahasiswa terlatih mengemukakan ide-ide dalam mengembangkan kemampuan berpikir kreatif mahasiswa (80\%).

Angket yang diberikan kepada mahasiswa terdiri dari empat substansi pernyataan, yaitu: model pembelajaran inductive thinking berbasis keterampilan proses sains merupakan model belajar yang baru dan cocok diterapkan dalam belajar IPA di kelas bagi mahasiswa, model pembelajaran inductive thinking berbasis keterampilan proses sains dapat membuat mahasiswa lebih termotivasi dalam pembelajaran, mengurangi kejenuhan mahasiswa dalam belajar di kelas, model pembelajaran inductive thinking berbasis keterampilan proses sains membantu mahasiswa untuk menguasai konsep-konsep IPA, model pembelajaran inductive thinking berbasis keterampilan proses sains membuat mahasiswa terlatih mengemukakan ide-ide.

c) Tanggapan Mahasiswa terhadap Model pembelajaran inductive thinking

Untuk mengetahui tanggapan mahasiswa terhadap model pembelajaran inductive thinking, diberikan skala sikap kepada mahasiswa. Angket yang diberikan kepada mahasiswa terdiri dari empat substansi pernyataan, yaitu: model pembelajaran inductive thinking merupakan model belajar yang baru dan cocok diterapkan dalam belajar IPA di kelas bagi mahasiswa, model pembelajaran inductive thinking dapat membuat mahasiswa lebih termotivasi dalam pembelajaran, mengurangi kejenuhan mahasiswa dalam belajar di kelas, model pembelajaran inductive thinking membantu mahasiswa untuk menguasai konsepkonsep IPA, model pembelajaran inductive thinking membuat mahasiswa terlatih mengemukakan ide-ide dalam mengembangkan kemampuan berpikir kreatif mahasiswa.

Model pembelajaran inductive thinking merupakan model belajar yang baru dan cocok diterapkan dalam belajar IPA di kelas bagi mahasiswa (85\%), model pembelajaran inductive thinking dapat membuat mahasiswa lebih termotivasi dalam pembelajaran, mengurangi kejenuhan mahasiswa dalam belajar 
di kelas (82\%), model pembelajaran inductive thinking membantu mahasiswa untuk menguasai konsepkonsep IPA (85\%), dan mahasiswa setuju bahwa model pembelajaran inductive thinking membuat mahasiswa terlatih mengemukakan ide-ide dalam mengembangkan kemampuan berpikir kreatif mahasiswa (70\%).

Untuk lebih jelasnya, persentase tanggapan mahasiswa terhadap model pembelajaran inductive thinking dapat dilihat pada gambar berikut ini:

4) Tanggapan Dosen terhadap Model Pembelajaran yang diterapkan

a) Tanggapan Dosen terhadap Model pembelajaran inductive thinking berbasis keterampilan proses sains

Untuk mengetahui tanggapan dosen terhadap model pembelajaran inductive thinking berbasis keterampilan proses sains, diberikan angket kepada dosen. Angket yang diberikan ke dosen untuk menanggapi proses pembelajaran terhadap model pembelajaran inductive thinking berbasis keterampilan proses sains terdiri dari empat substansi pernyataan, yaitu:

- Model pembelajaran inductive thinking berbasis keterampilan proses sains merupakan model pembelajaran yang efektif untuk diterapkan di kelas.
- Model pembelajaran inductive thinking berbasis keterampilan proses sains dapat meningkatkan penguasaan konsep dan kemampuan berpikir kreatif mahasiswa pada pokok bahasan listrik.

- Penerapan model pembelajaran inductive thinking berbasis keterampilan proses sains pada pokok bahasan lainnya.

- Model pembelajaran inductive thinking berbasis keterampilan proses sains dapat menghilangkan kejenuhan mahasiswa dalam belajar IPA di kelas.

b) Tanggapan Dosen terhadap Model Pembelajaran Inductive Thinking

Untuk mengetahui tanggapan dosen terhadap model pembelajaran inductive thinking, diberikan angket kepada mahasiswa. Angket yang diberikan kepada dosen terdiri dari empat substansi pertanyaan, yaitu:

- Model pembelajaran inductive thinking merupakan model pembelajaran yang efektif untuk diterapkan di kelas.

- Model pembelajaran inductive thinking dapat meningkatkan kemampuan kognitif dan kemampuan berpikir kreatif mahasiswa pada pokok bahasan listrik.

- Penerapan model pembelajaran inductive thinking pada pokok bahasan lainnya. 
- Model pembelajaran inductive thinking dapat menghilangkan kejenuhan mahasiswa dalam belajar IPA di kelas.

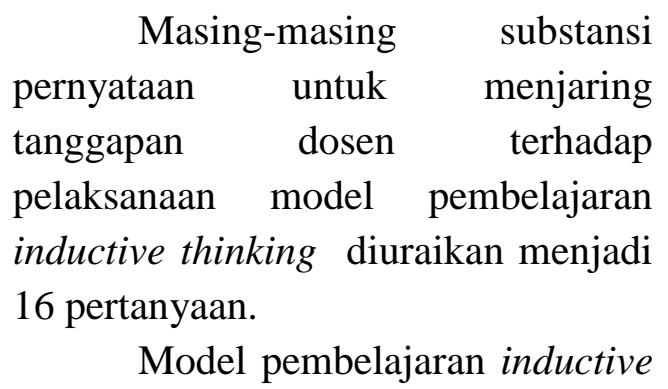
thinking merupakan model belajar yang baru dan cocok diterapkan dalam belajar IPA di kelas bagi mahasiswa dan model pembelajaran inductive thinking dapat membuat mahasiswa lebih termotivasi dalam pembelajaran, mengurangi kejenuhan mahasiswa dalam belajar di kelas, dosen pun menyatakan setuju bahwa bahwa model pembelajaran inductive thinking membantu mahasiswa untuk menguasai konsep-konsep IPA dan model pembelajaran inductive thinking membuat mahasiswa terlatih mengemukakan ide-ide dalam mengembangkan kemampuan berpikir kreatif mahasiswa.

Hasil perhitungan dan analisis untuk tanggapan dosen di atas menunjukkan bahwa dosen menyatakan setuju terhadap penerapan model pembelajaran inductive thinking di kelas.

\section{SIMPULAN}

Berdasarkan hasil penelitian dan pembahasan yang telah disajikan sebelumnya, dapat ditarik kesimpulan sebagai berikut:

1. Peningkatan kemampuan kognitif mahasiswa yang mengikuti pembelajaran inductive thinking berbasis keterampilan proses sains pada konsep listrik secara signifikan lebih tinggi dibandingkan pembelajaran inductive thinking.

2. Peningkatan keterampilan berfikir kreatif mahasiswa yang mengikuti pembelajaran inductive thinking berbasis keterampilan proses sains pada konsep listrik secara signifikan lebih tinggi dibandingkan pembelajaran inductive thinking.

3. Secara umum mahasiswa memberikan tanggapan yang baik terhadap pembelajaran inductive thinking berbasis keterampilan proses sains. Pembelajaran ini selain merupakan bentuk pembelajaran yang baru buat mereka, menyenangkan, juga sangat memotivasi mereka dalam belajar. Disisi lain pembelajaran ini dapat menjelaskan konsepkonsep yang bersifat abstrak sehingga konsep yang sebelumnya sulit menjadi mudah dipahami.

Berdasarkan penelitian yang telah dilakukan tentang pembelajaran inductive thinking berbasis keterampilan proses sains, peneliti mengajukan beberapa saran sebagai berikut: 
1. Komponen keterampilan berfikir kreatif yang dikaji dalam penelitian ini masih terbatas dalam enam komponen sehingga masih perlu penelitian lanjutan untuk komponen yang lainnya.

2. pembelajaran inductive thinking berbasis keterampilan proses sains yang dikembangkan dalam penelitian ini difokuskan untuk meningkatkan kemampuan kognitif mahasiswa pada materi listrik sehingga masih perlu penelitian lebih lanjut untuk konsep-konsep fisika lainnya yang bersifat abstrak.

\section{DAFTAR RUJUKAN}

Anderson, L W, \& Krathwohl D R (eds.) (2001). A Taxonomy for Learning, Teaching, and Assessing: A Revision of Bloom's Taxonomy of Educational Objectives. New York: Longman.

Arikunto, S. (2006). Prosedur Penelitian suatu Pendekatan Praktek. Edisi V. Jakarta: Rineka Cipta.

Hake, R. R. (1999). Analyzing Change/Gain Scores. [Online]. Tersedia:

http://lists.asu.edu/cgibin/wa?A2=ind $9903 \& \mathrm{~L}=$ aera$\underline{\mathrm{d} \& \mathrm{P}=\mathrm{R} 6855}$.

Haryono. 1997. Penelitian dan Pengembangan Model Proses Belajar yang Bercirikan
Peningkatan Kemampuan

Berpikir Kreatif dan Kritis

Siswa SD, Laporan Penelitian

Hibah Bersaing III/3

Perguruan Tinggi 1996/1997.

Semarang:Lemlit IKIP

Semarang.

Listyaningrum, Rahmawati. (2012).

Penerapan

Model

Pembelajaran

Inductive

Thinking berbasis

Keterampilan Proses Sains

Untuk Meningkatkan Kualitas

Pembelajaran Biologi Siswa. Jurnal Online

Sudjana, Nana. (2009). Metode Statistika. Bandung: PT Remaja Rosdakarya.

Sukmadinata, Nana. (2012). Metode Penelitian Pendidikan. Bandung: PT Remaja Rosdakarya.

Suwarna, I. P. (2005). Model Pembelajaran Listrik Dinamis untuk Meningkatkan Keterampilan Proses Sains dan Berpikir Kreatif Siswa SMP. Tesis, Bandung: PPS UPI: Tidak diterbitkan. 